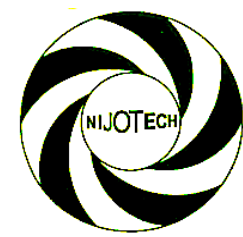

Nigerian Journal of Technology (NIJOTECH)

Vol. 37, No. 2, April 2018, pp. 346 - 357

Copyright@ Faculty of Engineering, University of Nigeria, Nsukka,

Print ISSN: 0331-8443, Electronic ISSN: 2467-8821 www.nijotech.com

http://dx.doi.org/10.4314/njt.v37i2.9

\title{
PROCESS OPTIMISATION AND CHARACTERISATION OF FRAGRANCE SUITED MECHANICALLY EXPRESSED NIGERIAN LIME SEED OIL
}

\author{
A. G. Adeniyi ${ }^{1}$, L. T. Adewoye ${ }^{2},{ }^{*}$ 0. A. A. Eletta ${ }^{3}, 0$. O. Ogunleye $^{4}$ and K. Olukotun ${ }^{5}$ \\ 1, 2,3,5, DePARTMENT OF CHEMICAL ENGINEERING, UNIVERSITY OF ILORIN, ILORIN, KWARA STATE. NIGERIA. \\ 4 Dept. of Chemical Engineering, Ladoke Akintola Univ. of TeChnology, Ogbomoso, Oyo State. Nigeria. \\ E-mail addresses: ${ }^{1}$ remson414@gmail.com; ${ }^{2}$ adewoye.tl@unilorin.edu.ng, ${ }^{3}$ modeletta@unilorin.edu.ng; \\ 4 ooogunleye@lautech.edu.ng, 5 olukotunken@gmail.com
}

\begin{abstract}
This study determined the optimal process parameters for the extraction of Lime (Citrus aurantifolia) Seed Oil (LSO) for fragrance production. A Box Behnken Design (BBD) of Response Surface Methodology (RSM) was used to design the LSO extraction using hydraulic press. The effect of various combinations of temperature, heating time and pressing time on oil yield, specific gravity, acid value, saponification value, FFA, Iodine and peroxide values were investigated. The oil produced was analysed using Gas Chromatography - Mass Spectrophotometer (GC-MS). The $R^{2}$ values of models ranged between 0.998 and 0.999 and adjusted $R^{2}$ between 0.994 and 0.998 . A maximum of $29.21 \%$ of LSO yield was obtained with specific gravity (0.861), acid value (2.86 mg KOH/g); saponification value (185.3 mg $\mathrm{KOH} / \mathrm{g}), \mathrm{FFA}(\leq 1.43 \%)$, Iodine value $(107.8 \mathrm{~g} \mathrm{I} / 100 \mathrm{~g})$ and peroxide value $(15 \mathrm{meq} / \mathrm{kg})$ at the optimal process parameters of $83^{\circ} \mathrm{C}, 8 \mathrm{~min}$ and $7 \mathrm{~min}$ temperature heating and pressing time respectively. The physico-chemical analysis of the lime seed oil indicated that the oil could be used for fragrance.
\end{abstract}

Keywords: Pollution, waste management, optimization, seed oils, GC-MS

\section{INTRODUCTION}

There has been increased interest in the extraction of oil from plants due to increase in their industrial applications $[1,2]$ and search for new sources of fats and oil continues to enhance the existing ones [3]. Oil from plant and animals could be used in the formulation of food, pharmaceuticals, skincare products, aromatherapies and lubricants [4, 5] depending on the source and the physico- chemical characteristics of such oils. Oil production is important to both small-to-medium scale industries as well as rural dwellers; creating job opportunities for substantial workforce and hence serving as source of income to many communities engaging in the production [6]. Citrus species have been identified as potential sources of oil which are well suited for edible and industrial applications [7]. Citrus oils are mixtures of very volatile components such as terpenes and oxygenated compounds. The oil is made up of constituents such as monoterpenes, sesquiterpenes, alcohols, esters and aldehydes [8]. These oils are used in the pharmaceutical, perfumery and food industries, and, the quality of the oil is related to the value of total aldehydes; basically citral content.

Prominent among these Citrus fruits that are sources of oil are, oranges, lemon, lime, grape and tangerine. Lime (Citrus aurantiforia) is an important citrus fruit crop in many countries and it is generally grown under both tropical and subtropical climatic conditions [9]. Its peels and seeds constitute the sources of oil. There are three major means of recovering oils from oil bearing biological materials: wet extraction, mechanical expression and solvent extraction [10]. Mechanical extraction process such as hydraulic press, expeller screw press and cold press is a more suitable method for both small and commercial operations compared to other methods because it requires simple equipment, low investment, low operating and maintenance cost and does not involve solvent separation [3, 11, 12]. Some pre-treatment operations known to influence oil yield in mechanical oil expression include heat treatment, moisture conditioning and size reduction as well as applied pressure $[13,14]$.

Citrus processing industries generate wastes (peels, seeds and pulp) corresponding to about $50 \%$ of the

\footnotetext{
* Corresponding author tel: +234-803-581- 7674
} 
raw processed fruit after the juice extraction [15]. The citrus peels and seeds from juice processing industries would ordinarily create environmental problems for various local communities with every ton of food waste translating to 4.5 tonnes of $\mathrm{CO}_{2}$ emissions [16]. Therefore, there is the need to find new and environment friendly techniques that could turn these wastes into assets. Many researches have been carried out on citrus peels and seeds including lime. Ajewole and Adeyeye [17] analysed the fatty acid composition of the oils extracted from six citrus seeds (Citrus sinesis, Citrus paradisi, Citrus auranthum, Citrus reticulata, Citrus aurantilolia and Citrus tangelo) using soxhlet extraction method and the results showed high degrees of unsaturation between 67.3 and 86.2\%. Anwar et al. [18] investigated the physicochemical characteristics and fatty acid profiles of oil extracted from four citrus species (Citrus limetta, Citrus paradisi, Citrus sinensis and Citrus reticulata) using soxhlet extraction method. Manaf et al. [19] determined the proximate composition of musk lime seeds and the physicochemical properties of the oil derived from the seeds to establish potential applications of the oil. Aranha and Jorge [20] characterized the seeds of orange varieties (Hamlin, Natal, Perario and Valencia) on the composition and physico-chemical properties of its oil through the determination of free fatty acids, peroxide value, refraction, iodine value, saponification value, unsaponifiable matter, oxidative stability and fatty acid profile. Reazai et al. [21] investigated seed oils of more commonly found citrus fruits in Iran and determined the oil yield and fatty acid composition of the neutral lipid classes of seed oils.

For all these previous studies, the extractions were largely solvent based, the effects of extraction parameters on the oil properties were not considered and the oils were not targeted towards any particular industrial use. This study was therefore carried out to study the effects of extraction parameters on the oil yield, properties and develop an optimization framework for the extraction of lime seed oil whose properties are well suited for fragrance production using a hydraulic press.

\section{MATERIALS AND METHODS}

\subsection{Lime seeds Collection and Preparation}

The lime fruits (Citrus aurantifolia) used for this study were obtained from a local citrus market in Ilorin, Kwara State, Nigeria. The fruits were de-pulped to obtain the seeds. The seeds were cleaned with distilled water, air dried and then decorticated by winnowing to remove the hull from the seeds and, thereafter weighed $\left(\mathrm{W}_{1}\right)$. The processed seeds were then oven dried at 60 ${ }^{\circ} \mathrm{C}$ until constant weight $\left(\mathrm{W}_{2}\right)$ was obtained following methods of Liauw et al. [22]; the oven dried seeds were ground and sieved using a $0.5 \mathrm{~mm}$ screen size based on a previous recommendation of Kasote et al. [23] The moisture content in percentage wet basis was determined to be $6.35 \%$ using equation (1):

$$
\text { Moisture Content }(\%)=\frac{\left(W_{1}-W_{2}\right)}{W_{1}} \times 100
$$

Where: $W_{1}$ is the original weight of the lime seed before drying and $W_{2}$ is the weight of the sample after drying.

\subsection{Oil Extraction Procedure}

A Box Behnken Design (BBD) of Response Surface Methodology (RSM) was used to design the extraction of the LSO (using a $10 \mathrm{MPa}$ rated hydraulic press). As stated by Kasote et al. [23] and Olajide et al. [24], the most important process parameters during mechanical oil expression are the moisture content of the feed materials, temperature of drying, pressing time, applied pressure and the heating time. The hydraulic press used in this study is as shown in Figure 1, operating at an average pressure of $10 \mathrm{MPa}( \pm 0.5)$. In this study, the moisture content and the pressure were $6.35 \%$ and $10 \mathrm{MPa}$, respectively while the BBD design parameters for LSO were, Temperature $\left(\mathrm{X}_{1}\right)$, Heating Time $\left(\mathrm{X}_{2}\right)$ and Pressing Time $\left(\mathrm{X}_{3}\right)$. The selected ranges for these parameters were based on the LSO fragrance requirements by Codex Alimentarium Commission [25] and IFRA [26] as shown in Table 1.

Table 1: BBD experimental Increments, values of coded levels of LSO extraction

\begin{tabular}{|c|c|c|c|c|c|}
\hline \multirow{2}{*}{ Variables } & \multirow{2}{*}{ Symbols } & \multirow{2}{*}{$\begin{array}{c} \pm \\
\text { Increment } \\
\Delta \mathrm{X}\end{array}$} & \multicolumn{3}{|c|}{ Coded Factor Levels } \\
\hline & & & -1 & 0 & 1 \\
\hline Temperature $\left({ }^{\circ} \mathrm{C}\right)$ & $\mathrm{X}_{1}$ & \pm 5 & 80 & 85 & 90 \\
\hline Heating Time (min) & $\mathrm{X}_{2}$ & \pm 1 & 6 & 7 & 8 \\
\hline Pressing Time (min) & $\mathrm{X}_{3}$ & \pm 1 & 5 & 6 & 7 \\
\hline
\end{tabular}

Pre-treated lime seeds of $30 \mathrm{~g}$ weight were used for each experiment and the pre-treated lime seeds were pressed using a hydraulic press. The extracted oil was placed in a dark container and stored to allow gravity settling of foreign materials thereafter, the oil was filtered to remove the settled particles. The oil was weighed, and the percentage oil yield was calculated using equation 2 :

$$
\text { Oil Yield }(\%)=\frac{m_{o}}{m_{s}} \times 100
$$


Where: $m_{o}$, represents the weight of oil extract and $m_{s}$, represents the weight of sample.

At the end of each operation, the weight of oil expelled and mass of cake was recorded.

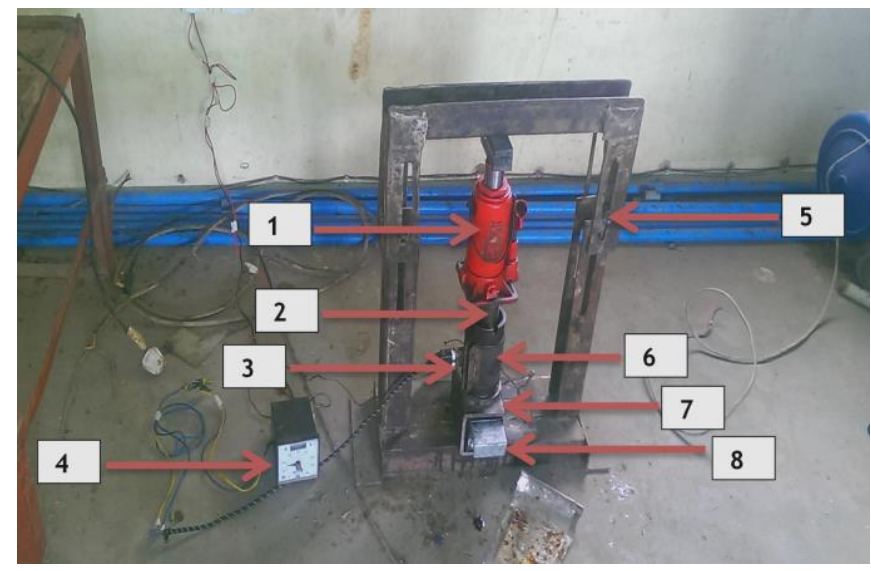

Figure 1: Experimental Setup

1. Hydraulic jack 2. Piston 3. Barrel heater 4. Thermostat 5. Press frame 6. Barrel 7. Strainer 8. Oil collector

\subsection{Method of Analysis}

The seed oil obtained was analyzed for fatty oil composition using Gas Chromatography Mass Spectrometry (GC-MS AGILENT 5789A). Fatty acid profile of the extracted lime seed oil was determined using Gas Chromatography (HP 6890 powered with HP ChemStation Rev. A 09.01 [1206] Software). The physical and chemical properties of the LSO comprising of specific gravity, acid value, saponification value, Free Fatty Acid (FFA), Iodine value and peroxide value were determined based on the methods described by the Association of Official Analytical Chemists [27]. Each experiment was carried out in triplicate to ensure reproducibility and, the mean values are reported.

\subsubsection{Determination of Specific Gravity}

Dried specific gravity bottle was filled with the oil sample in such a manner that prevented entrapment of air bubbles and then the stopper was inserted into the bottle. The filled bottle was immersed in water bath at $30^{\circ} \mathrm{C}$ and held for 30 minutes. Oil that came out of the capillary opening of the bottle was carefully wipe off and then removed from the bath, cleansed and dried thoroughly. This was quickly weighed ensuring that the temperature did not fall below $30^{\circ} \mathrm{C}$ and then the specific gravity value of the oil sample was computed according to equation (3):

$$
\text { Specific Gravity at } 30^{\circ} C=\frac{A-B}{C-B}
$$

Where, $A=$ weight in grams of specific gravity bottle with oil at $30^{\circ} \mathrm{C} ; \mathrm{B}=$ weight in grams of specific gravity bottle at $30^{\circ} \mathrm{C}$; $\mathrm{C}=$ weight in grams of specific gravity bottle with water at $30^{\circ} \mathrm{C}$

\subsubsection{Determination of Acid Value}

Oil sample (2g) was weighed into a $250 \mathrm{ml}$ conical flask; to this was added, $25 \mathrm{ml}$ of ethanol and $1 \mathrm{ml}$ of phenolphthalein indicator solution. The mixture was boiled for 5 minutes and then titrated while hot against $0.1 \mathrm{M} \mathrm{KOH}$ solution. The endpoint was reached when pink colour persisted for 30 seconds. The acid value was calculated using equation (4):

$$
\text { Acid Value }=\frac{56.1 \times V \times C}{M}
$$

Where: $\mathrm{V}$ is volume of $\mathrm{KOH}(\mathrm{ml}), \mathrm{C}$ is concentration of $\mathrm{KOH}, \mathrm{M}$ is mass of the test portion ( $\mathrm{g}$ ), and 56.1 is the molar mass of $\mathrm{KOH}$.

\subsubsection{Determination of Free Fatty Acid}

The acidity is frequently expressed as Free Fatty Acid (FFA) for which calculation was made using equation (5):

$$
\text { FFA as Oleic } \text { Acid }=\frac{28.2 \times V \times C}{M}(\%)
$$

\subsubsection{Determination of Saponification Value}

Oil sample (2.5 g) was weighed into a conical flask and, to this was added $25 \mathrm{ml}$ of alcoholic KOH. A blank sample was also prepared in another conical flask. The mixture was refluxed on a water bath for 1 hour, boiled gently but steadily until saponification is complete, as indicated by absence of any oily matter and appearance of clear solution. To the cooled solution was added, $1 \mathrm{ml}$ of phenolphthalein indicator and the contents of the two flasks were titrated with $0.5 \mathrm{M} \mathrm{HCl}$. The saponification value was then calculated using equation (6):

$$
\text { Saponification Value }=\frac{(S-B) \times C \times 56.1}{M}(\%)
$$

Where $S$ is the sample titre value; $B$ is the blank titre value, $\mathrm{C}$ is the concentration of the $\mathrm{HCl}, 56.1$ is the molecular weight of $\mathrm{KOH}$ and $\mathrm{M}$ is the weight of the sample.

\subsubsection{Determination of Iodine Value}

About $2 \mathrm{~g}$ of oil sample was weighed into a $500 \mathrm{ml}$ flask and then $20 \mathrm{ml}$ of carbon tetrachloride and $25 \mathrm{ml}$ of DAM's reagent was added to the flask, cocked and vigorously swirled. The swirled flask was placed in the dark for 1 hour 30 minutes, after which, $20 \mathrm{ml}$ of potassium iodide solution and $150 \mathrm{ml}$ of water were added and titrated with $0.1 \mathrm{~mol} / \mathrm{l}$ sodium thiosulphate solution until the yellow colour is noticed. Thereafter, a few drops of starch was added and, titration continued 
until the blue colour disappears with shaking. The same procedure was used for the blank and the iodine value was calculated using equation (7):

$$
\text { Iodine Value }=\frac{12.69(B-S) \times C}{M}
$$

where, $\mathrm{C}$ is the concentration of sodium thiosulphate; $\mathrm{B}$ is the volume in $\mathrm{ml}$ of standard sodium thiosulphate used for blank; $\mathrm{S}$ is the volume in $\mathrm{ml}$ of standards sodium thiosulphate used for the sample and $M$ is the mass of the sample.

\subsubsection{Determination of Peroxide Value}

$1 \mathrm{~g}$ oil sample was weighed into a clean, dry boiling tube; to this was added, $1 \mathrm{ml}$ of freshly prepared saturated potassium iodide solution and $20 \mathrm{ml}$ of solvent mixture (2 volume of glacial acetic acid +1 volume of chloroform) and the tube was shaken vigorously for 30 seconds to allow the mixture to react. $50 \mathrm{ml}$ of distilled water was added to the mixture and titrated with $0.01 \mathrm{M}$ sodium thiosulphate solution using $1 \mathrm{ml}$ starch solution as indicator. Shaking during titration continued until the blue colour disappeared. A blank titration was carried out and, the peroxide value was calculated using equation (8).

$$
\text { Peroxide Value }=\frac{\left(V_{1}-V_{o}\right) \times C \times 1000 \times T}{M}
$$

where, $\mathrm{V}_{1}$ is the volume of $0.01 \mathrm{M}$ sodium thiosulfate solution consumed in the main test; $\mathrm{V}_{0}$ is the volume of $0.01 \mathrm{M}$ sodium thiosulfate solution consumed in the blank test; $\mathrm{C}$ is the molar concentration of the sodium thiosulfate solution; $\mathrm{T}$ is the titre of the thiosulfate solution and $M$ is the mass of oil sample in grams

\subsection{Analysis of Data and Optimization}

Regression analysis of the experimental data to fit the response equation in terms of the factors was carried out and, the quality of fit of the model was expressed by the correlation coefficient (R-squared) and Analysis of Variance (ANOVA). A second order polynomial equation was proposed to fit the experimental data as given in equation (9):

$$
\begin{aligned}
Y_{i}=a_{0}+a_{1} X_{1}+ & a_{21} X_{2}+a_{3} X_{3}+a_{11} X_{1}^{2}+a_{22} X_{2}^{2} \\
& +a_{33} X_{3}^{2}+a_{12} X_{1} X_{2}+a_{13} X_{1} X_{3} \\
& +a_{23} X_{2} X_{3}
\end{aligned}
$$

where $Y_{i}(\mathrm{i}=1,2 \ldots 7)$ is the predicted response for oil yield, specific gravity, acid value, saponification value, FFA, Iodine value and peroxide values, respectively while $\mathrm{a}_{0}$ is the value of the fitted response at the centre point of the design, $a_{i}, a_{i i}, a_{i j}$ being the linear, quadratic, and cross product terms, respectively. A statistical optimization of the model was conducted using the RSM while the BBD was used to determine the main and interaction effects of all the process parameters.

\section{RESULTS AND DISCUSSION}

\subsection{Effect of Process Parameters on Oil Yield and} Physico-Chemical Properties of LSO

The process parameters are vital to the quantity and quality of the extracted oil $[23,24]$ and; the physicochemical properties are used to determine the quality of oil sample $[25,26]$. The effects of process parameters on LSO oil yield, specific gravity, acid value, saponification value, FFA, Iodine value and peroxide values are as presented in Figures 2, 3, 4, 5, 6, 7 and 8, respectively.

The LSO yield increased with heating time but reduced with increase in temperature (fig 2a). It also increased with pressing time and decreased with an increase in temperature as shown in Figure 2a. The oil yield ranged between $22.31 \%$ and $30.10 \%$. This result agrees with Ajewole and Adeyeye [17] that reported Nigerian citrus oil recovery of between 25 and $40 \%$. However, the trend for specific gravity was that, the specific gravity decreased with increase in temperature, heating time (Figure 3a) and pressing time (Figure 3b). Codex Alimentarium Commission [28] stipulated that, the specific gravity for a quality citrus oil should range between 0.855 and 0.863 and in this study, the process parameters favoured this condition.

The acid value and FFA are related to hydrolytic reactions development in the oil. Codex Alimentarium Commission [25] stipulated that crude seed oil quality should have a maximum of $4.0 \mathrm{mg} \mathrm{KOH} / \mathrm{g}$ acid value. It is observed that the oils analysed have acid values ranging between 2.62 and $3.10 \mathrm{mg} \mathrm{KOH} / \mathrm{g}$ which are within limits allowed for crude seed oils. This is as shown in Figure 4a and 4b where acid values decreased with increase in temperature and heating time, temperature and pressing time, respectively.

The effect of process parameters on saponification value is as shown in Figure 5. Its values ranged between 177 and $196 \mathrm{mgKOH} / \mathrm{g}$. Some of these values are slightly higher than those reported in literature for common seed oils $[29,30]$. The high saponification value of the oil has been attributed to the formation of lower molecular weight oxidation product suggesting high proportion of unsaturated fatty acid [31, 32]. The high saponification values suggest the potential application in the production of soap and shampoos $[32,33]$.

FFA followed this same trend as that of acid values as presented in Figure 6. This difference may be due to factors that caused changes in the formation of free 
fatty acids from the hydrolysis of glycerides, such as heat, light and enzymatic action [30,31].

Iodine value measures the degree of unsaturation in a fat or vegetable oil. It determines the stability of oils to oxidation, and allows the overall unsaturation of the fat to be determined qualitatively [34]. In accordance with the amount of iodine, vegetable oils can be classified into siccative ( $>130 \mathrm{~g} \mathrm{I}_{2} / 100 \mathrm{~g}$ ), semi-siccative (115 $\left.130 \mathrm{~g} \mathrm{I}_{2} / 100 \mathrm{~g}\right)$ and non-siccative $\left(<115 \mathrm{~g} \mathrm{I}_{2} / 100 \mathrm{~g}\right)$
[35]. It was observed that, the iodine value reduced with increasing temperature, heating time and pressing time as shown in Figure $7 \mathrm{a}$ and $7 \mathrm{~b}$. The values ranged between 101.38 and $108.39 \mathrm{~g} \mathrm{I}_{2} / \mathrm{k} \mathrm{g}$ and indicates that the oil is semi -siccative. By implication, the oil can be easily converted into semi - drying oil for use in the production of fragrance, while it may also be used as non-drying oil in the lubricant industry [36].

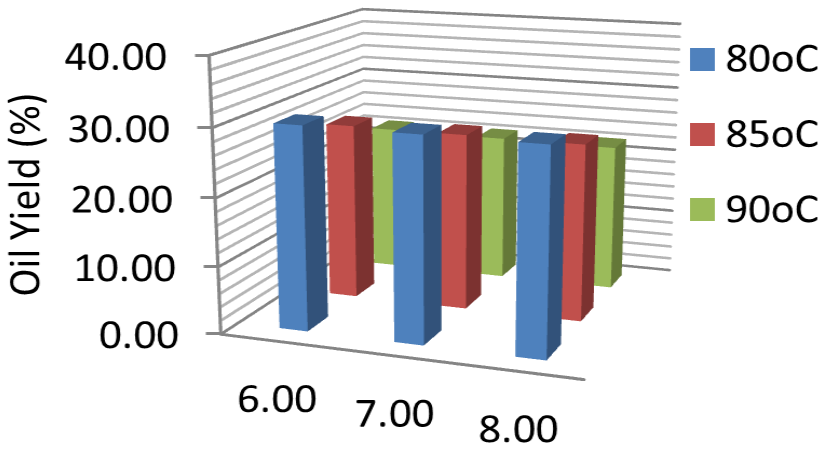

Preheating Time (Minutes)

A

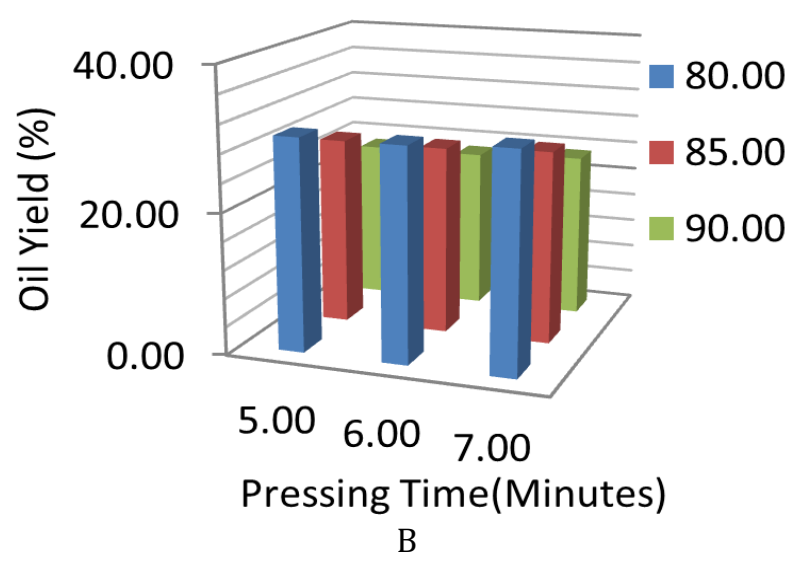

Figure 2: Effect of Extraction Parameters on Oil Yield (a) Preheating Temperature vs Time (b) Preheating Temperature vs Pressing Time

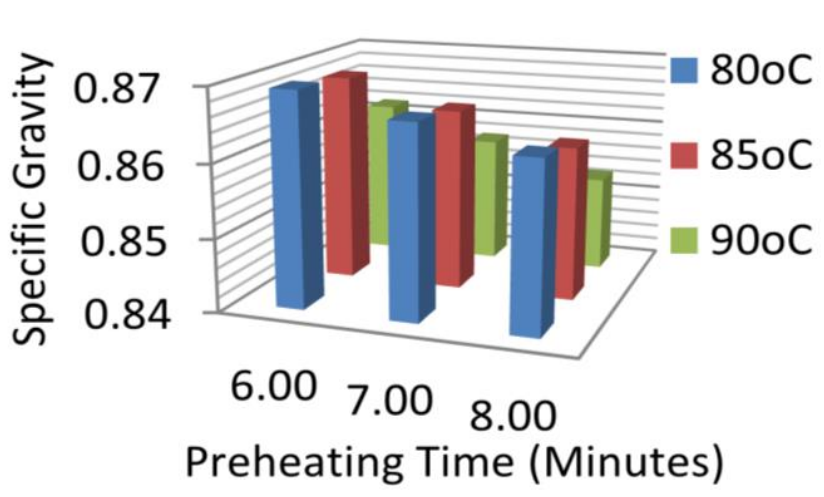

A

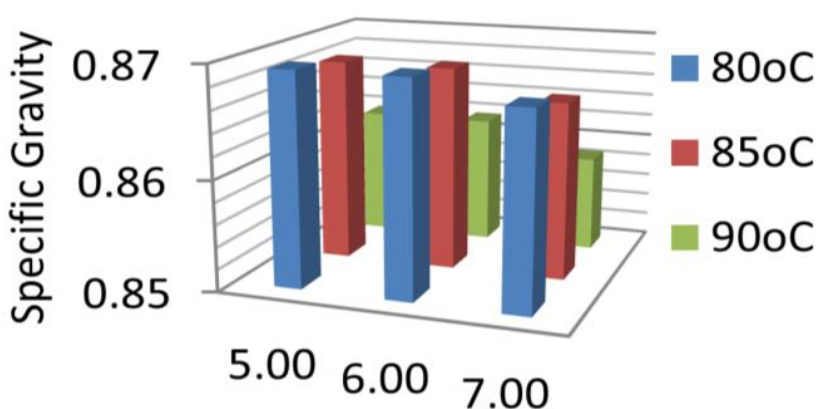

Pressing Time (Minutes)

B

Figure 3: Effect of Extraction Parameters on Specific Gravity (a) Preheating Temperature vs Time (b) Preheating Temperature vs Pressing Time

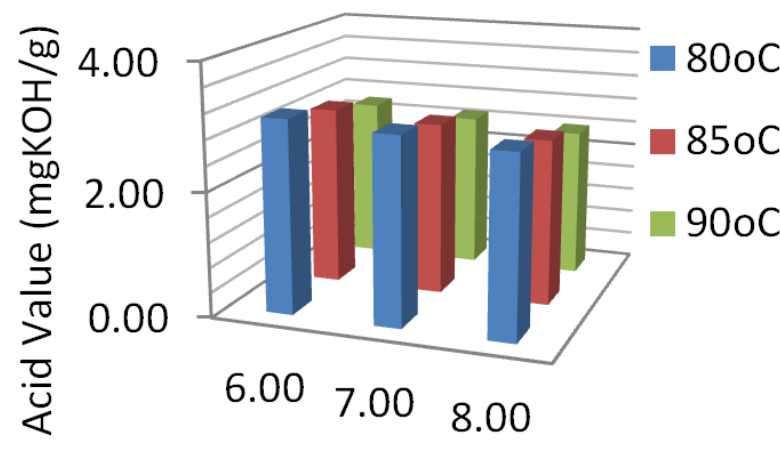

Preheating Time (Minutes)

A

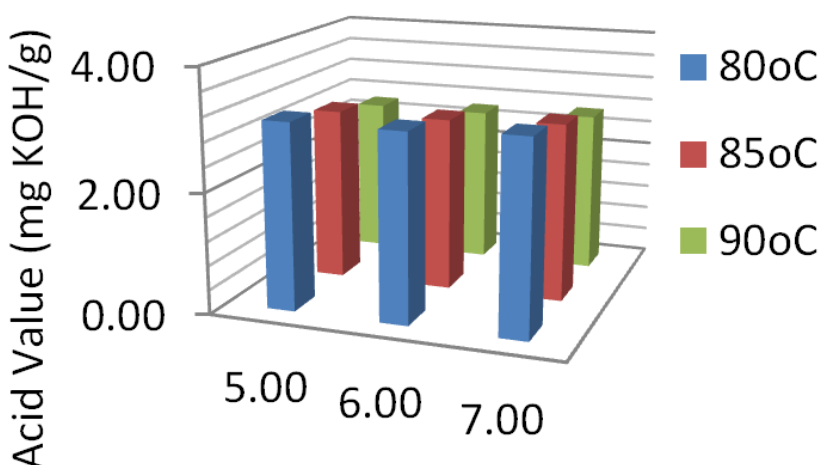

Pressing Time (Minutes)

B

Figure 4: Effect of Extraction Parameters on Acid value (a) Preheating Temperature vs Time (b) Preheating Temperature vs Pressing Time 
Process Optimisation and Characterisation of Fragrance Suited Mechanically Expressed Nigerian ..., A. G. Adeniyi, et al.

Peroxide value is used as a measure of the extent to which rancidity reactions have occurred during storage and could also be used as an indication of the quality and stability of fats and oils [34]. It was found to range from 13.63 to $19.78 \mathrm{meq} / \mathrm{kg}$ as shown in Figure 8 where its value reduced with increasing temperature, heating time and pressing time. Oils with high peroxide values are unstable and easily become rancid [37]. The results obtained show that, peroxide values were mostly higher than the standard values for vegetable oil (below $15 \mathrm{meq} / \mathrm{kg}$ ) reported in the literature [38, 39]. This implies that the oil in its crude form will not be suitable as edible oil but, this oil could find other uses in the industry.

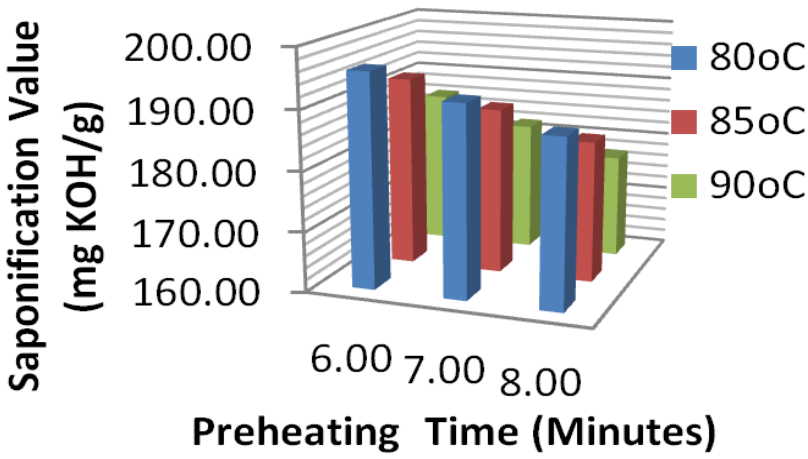

A
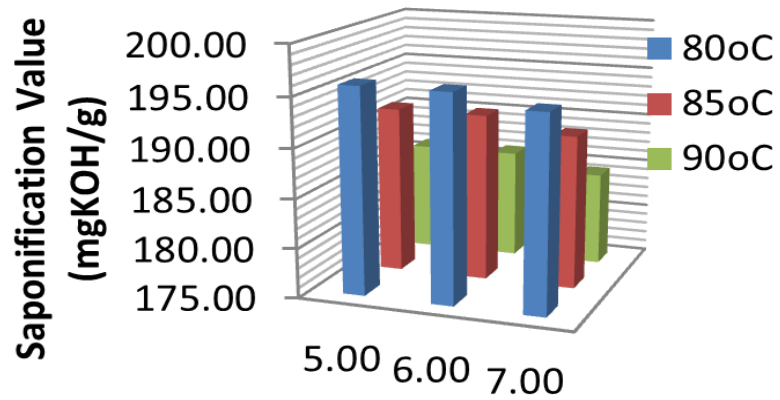

Pressing Time (Minutes)

B

Figure 5: Effect of Extraction Parameters on Saponification value (a) Preheating Temperature vs Time (b) Preheating Temperature vs Pressing Time

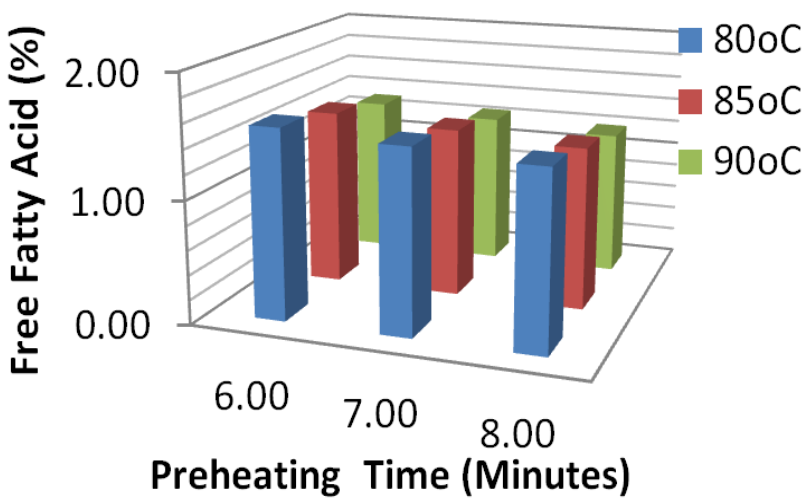

A

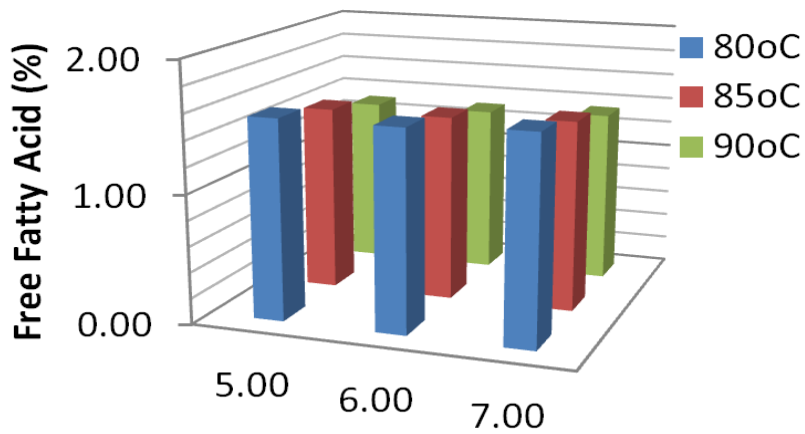

Pressing Time (Minutes)

B

Figure 6: Effect of Extraction Parameters on FFA (a) Preheating Temperature vs Time (b) Preheating Temperature vs Pressing Time

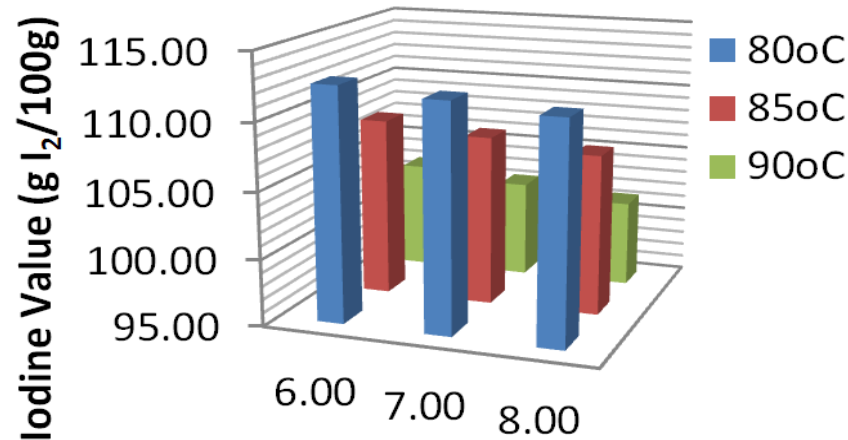

Preheating Time (Minutes)

A
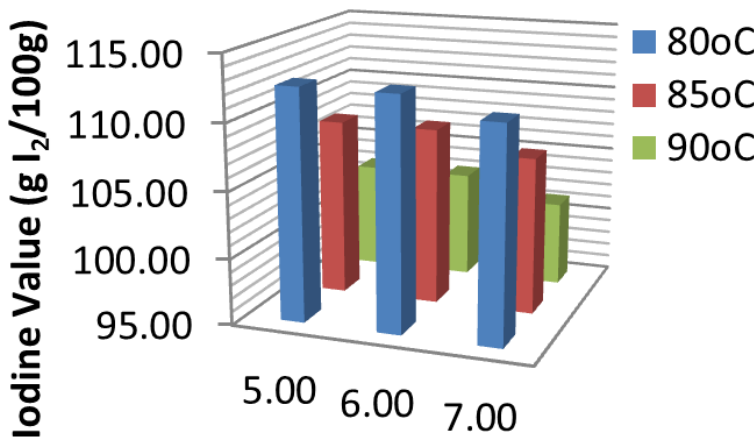

Pressing Time (Minutes)

B

Figure 7: Effect of Extraction Parameters on Iodine value (a) Preheating Temperature vs Time (b) Preheating Temperature vs Pressing Time 


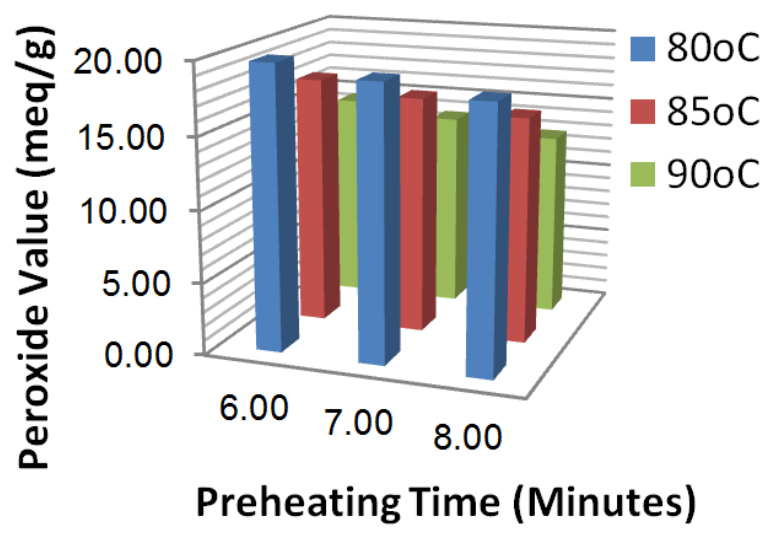

A

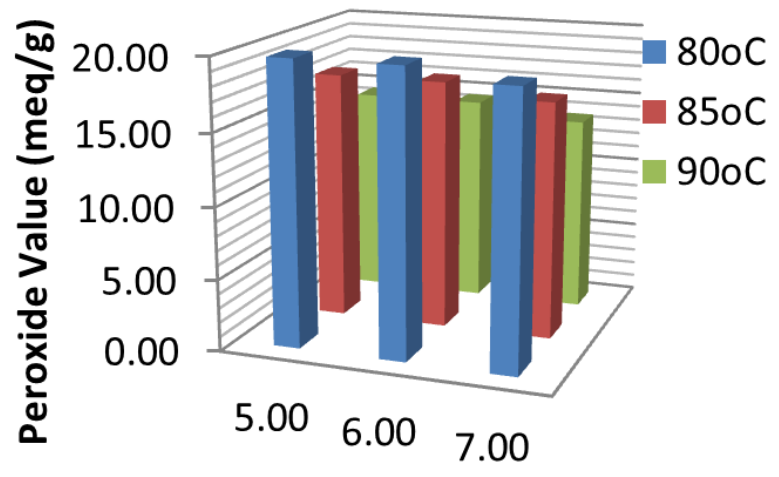

Pressing Time (Minutes)

B

Figure 8: Effect of Extraction Parameters on Peroxide value (a) Preheating Temperature vs Time (b) Preheating Temperature vs Pressing Time

\subsection{Optimization of Lime Seed Oil Extraction}

The LSO yield $\left(\mathrm{Y}_{1}\right)$ as well as the corresponding specific gravity $\left(\mathrm{Y}_{2}\right)$, acid value $\left(\mathrm{Y}_{3}\right)$, saponification value $\left(\mathrm{Y}_{4}\right)$, FFA $\left(\mathrm{Y}_{5}\right)$, Iodine value $\left(\mathrm{Y}_{6}\right)$ and peroxide value $\left(\mathrm{Y}_{7}\right)$ obtained from experiments conducted based on various combination of factors (heating temperature $\mathrm{X}_{1}$, heating time- $\mathrm{X}_{2}$ and pressing time $-\mathrm{X}_{3}$ ) using the BBD are shown in Table 2. The estimated coefficients of the terms of the model (equation 9) for $Y_{1}, Y_{2}$, $\mathrm{Y}_{3}, \mathrm{Y}_{4}, \mathrm{Y}_{5}, \mathrm{Y}_{6}$ and $\mathrm{Y}_{7}$ in terms of $\mathrm{X}_{1}, \mathrm{X}_{2}$ and $\mathrm{X}_{3}$ using RSM and its functional significance are as presented in Table 3. Analysis of Variance (ANOVA) of the models is as presented in Table 4. Terms whose levels of significance (p-value) are below 0.05 are asterisked and were included in the final models (equations 10 -
16). The $R^{2}$-values ranged between 0.998 and 0.999 and adjusted $\mathrm{R}^{2}$ between 0.994 and 0.998 . These $\mathrm{R}^{2}$ values agree with the predicted $R^{2}$ values and show high correlation between actual and predicted values of the responses. Adequate precision measures the signal to noise ratio. A ratio greater than 4 is desirable and the ratio in this study ranged between 62.845 and 1687.292 which indicates an adequate signal and confirms that the model can be used to navigate the design space. The coefficient of variation (CV) as the ratio of the standard error of estimate to the mean value of the observed response is a measure of reproducibility of the model.

Table 2: BBD experimental design and responses for LSO extraction

\begin{tabular}{|c|c|c|c|c|c|c|c|c|c|c|}
\hline \multirow{3}{*}{$\begin{array}{l}\text { Run } \\
\text { No }\end{array}$} & \multicolumn{3}{|c|}{ Extraction Factors } & \multicolumn{7}{|c|}{ RESPONSES (Oil quantity and quality) } \\
\hline & $\begin{array}{l}\text { Temp. } \\
\left(\mathrm{X}_{1}\right)\end{array}$ & $\begin{array}{l}\text { Heating } \\
\text { Time }\left(\mathrm{X}_{2}\right)\end{array}$ & $\begin{array}{c}\text { Pressing } \\
\text { Time } \\
\left(\mathrm{X}_{3}\right)\end{array}$ & $\mathrm{Y}_{1}$ & $\mathrm{Y}_{2}$ & $\mathrm{Y}_{3}$ & $\mathrm{Y}_{4}$ & $Y_{5}$ & $\mathrm{Y}_{6}$ & $\mathrm{Y}_{7}$ \\
\hline & $\left({ }^{o} \mathrm{C}\right)$ & (Min.) & (Min.) & $(\%)$ & - & $(\mathrm{mgKOH} / \mathrm{g})$ & $(\mathrm{mgKOH} / \mathrm{g})$ & $(\%)$ & $\left(g I_{2} / g\right)$ & $\underset{(m e q}{(m g}$ \\
\hline 1 & 90.00 & 6.00 & 6.00 & 22.62 & 0.861 & 2.62 & 186.0 & 1.31 & 103.1 & 14.5 \\
\hline 2 & 85.00 & 7.00 & 6.00 & 27.25 & 0.866 & 2.84 & 190.5 & 1.42 & 106.4 & 14.7 \\
\hline 3 & 85.00 & 8.00 & 5.00 & 27.25 & 0.866 & 2.72 & 190.2 & 1.36 & 106.0 & 13.0 \\
\hline 4 & 85.00 & 7.00 & 6.00 & 27.31 & 0.866 & 2.83 & 190.5 & 1.42 & 106.4 & 14.6 \\
\hline 5 & 80.00 & 8.00 & 6.00 & 30.00 & 0.863 & 2.89 & 188.0 & 1.44 & 111.4 & 18.2 \\
\hline 6 & 80.00 & 7.00 & 7.00 & 30.00 & 0.864 & 3.00 & 188.2 & 1.50 & 111.8 & 19.9 \\
\hline 7 & 85.00 & 7.00 & 6.00 & 27.30 & 0.866 & 2.83 & 190.5 & 1.41 & 106.4 & 14.9 \\
\hline 8 & 85.00 & 7.00 & 6.00 & 27.28 & 0.866 & 2.82 & 190.5 & 1.41 & 106.4 & 14.8 \\
\hline 9 & 85.00 & 6.00 & 7.00 & 27.26 & 0.866 & 2.95 & 190.5 & 1.48 & 106.8 & 16.5 \\
\hline 10 & 85.00 & 8.00 & 7.00 & 27.33 & 0.859 & 2.75 & 183.2 & 1.38 & 104.9 & 14.1 \\
\hline 11 & 85.00 & 6.00 & 5.00 & 26.98 & 0.872 & 2.90 & 196.8 & 1.45 & 108.1 & 15.7 \\
\hline 12 & 85.00 & 7.00 & 6.00 & 27.28 & 0.866 & 2.84 & 190.5 & 1.42 & 106.4 & 14.5 \\
\hline 13 & 90.00 & 7.00 & 5.00 & 22.61 & 0.861 & 2.51 & 185.9 & 1.25 & 102.6 & 12.8 \\
\hline 14 & 90.00 & 7.00 & 7.00 & 22.32 & 0.853 & 2.51 & 177.6 & 1.25 & 101.8 & 14.5 \\
\hline 15 & 90.00 & 8.00 & 6.00 & 22.31 & 0.853 & 2.39 & 177.4 & 1.19 & 101.4 & 12.8 \\
\hline 16 & 80.00 & 7.00 & 5.00 & 29.35 & 0.868 & 2.92 & 193.2 & 1.46 & 113.4 & 19.8 \\
\hline 17 & 80.00 & 6.00 & 6.00 & 29.35 & 0.869 & 3.11 & 193.3 & 1.55 & 113.8 & 21.6 \\
\hline
\end{tabular}


Generally, a model can be considered reasonably reproducible if its $\mathrm{CV}$ is not greater than 10 per cent $[40,41]$ hence, low values obtained for the coefficient of variation indicate high precision and reliability of the experiments and these ranged between 0.014 and 0.73 $\%$. Given all these positive indices, the models developed was successful in relating the process variables to the selected chemical and physical characteristics of LSO. As presented in Table 4, the Fvalues which ranged between 319.13 and 210200.22 implies that the model terms were significant. The lack of fit is designed to determine if, the adequacy of the selected model is sufficient to describe the observed data, or whether a more complicated model should be used. As shown in Table 4, the p-value of the lack of fit of the models were greater than 0.05 which are not significant and this indicates significant correlation between the independent and dependent variables.

The resulting models for LSO yield $\left(\mathrm{Y}_{1}\right)$ as well as the corresponding specific gravity $\left(\mathrm{Y}_{2}\right)$, acid value $\left(\mathrm{Y}_{3}\right)$, saponification value $\left(\mathrm{Y}_{4}\right)$, FFA $\left(\mathrm{Y}_{5}\right)$, Iodine value $\left(\mathrm{Y}_{6}\right)$ and peroxide value $\left(\mathrm{Y}_{7}\right)$ in terms of heating temperature $\left(\mathrm{X}_{1}\right)$, heating time $\left(\mathrm{X}_{2}\right)$ and pressing time $\left(\mathrm{X}_{3}\right)$ are equations $10,11,12,13,14,15$ and 16, respectively.

Table 3: Estimated coefficients of the fitted quadratic equation for different responses.

\begin{tabular}{|c|c|c|c|c|c|c|c|}
\hline \multirow{3}{*}{ Terms } & \multicolumn{7}{|c|}{ Estimated Coefficients of terms with p-value } \\
\hline & Oil Yield: & $\begin{array}{l}\text { Specific } \\
\text { Gravity }\end{array}$ & $\begin{array}{c}\text { Acid } \\
\text { Value }\end{array}$ & $\begin{array}{c}\text { Saponification } \\
\text { Value }\end{array}$ & FFA & $\begin{array}{l}\text { Iodine } \\
\text { value }\end{array}$ & $\begin{array}{l}\text { Peroxide } \\
\text { Value }\end{array}$ \\
\hline & $\mathrm{Y}_{1}$ & $\mathrm{Y}_{2}$ & $\mathrm{Y}_{3}$ & $\mathrm{Y}_{4}$ & $Y_{5}$ & $\mathrm{Y}_{6}$ & $\mathrm{Y}_{7}$ \\
\hline Const. & $-309.70^{*}$ & $-0.38^{*}$ & $-20.80^{*}$ & $190.50^{*}$ & $-10.40^{*}$ & $542.15^{*}$ & $753.52 *$ \\
\hline $\mathrm{X}_{1}$ & $7.8832^{*}$ & $0.0287^{*}$ & $0.5897^{*}$ & $-4.49^{*}$ & $0.295^{*}$ & $-8.34^{*}$ & $-15.32 *$ \\
\hline $\mathrm{X}_{2}$ & $4.9401^{*}$ & $0.0135^{*}$ & $-0.1646^{*}$ & $-3.47^{*}$ & $-0.082^{*}$ & $-5.11^{*}$ & $-9.78^{*}$ \\
\hline $\mathrm{X}_{3}$ & $4.9138^{*}$ & $0.0135^{*}$ & $0.4864^{*}$ & $-3.32^{*}$ & $0.2432^{*}$ & $-4.66^{*}$ & $-7.96^{*}$ \\
\hline $\mathrm{X}_{1}{ }^{2}$ & $-0.0470^{*}$ & $-0.0002^{*}$ & $-0.0036^{*}$ & $-4.13^{*}$ & $-0.002^{*}$ & $0.04^{*}$ & $0.08^{*}$ \\
\hline $\mathrm{X}_{2}{ }^{2}$ & $-0.0393^{*}$ & $-0.0002^{*}$ & 0.0103 & $-0.16^{*}$ & 0.005 & $0.03^{*}$ & 0.09 \\
\hline $\mathrm{X}_{3}^{2}$ & $-0.0393^{*}$ & $-0.0002^{*}$ & -0.0070 & $-0.16^{*}$ & -0.0035 & $0.03^{*}$ & 0.09 \\
\hline $\mathrm{X}_{1} \mathrm{X}_{2}$ & $-0.0473^{*}$ & $-0.0002^{*}$ & -0.0007 & $-0.83^{*}$ & -0.0003 & $0.04^{*}$ & $0.08^{*}$ \\
\hline $\mathrm{X}_{1} \mathrm{X}_{3}$ & $-0.0473^{*}$ & $-0.0002^{*}$ & $-0.0042^{*}$ & $-0.83^{*}$ & $-0.002^{*}$ & $0.04^{*}$ & $0.08^{*}$ \\
\hline $\mathrm{X}_{2} \mathrm{X}_{3}$ & $-0.0473^{*}$ & $-0.0002^{*}$ & -0.0042 & $-0.17^{*}$ & -0.0021 & $0.04^{*}$ & 0.08 \\
\hline $\mathrm{R}^{2}$ & 0.998 & 0.998 & 0.998 & 0.999 & 0.998 & 0.999 & 0.999 \\
\hline Adj. $R^{2}$ & 0.996 & 0.996 & 0.994 & 0.998 & 0.994 & 0.998 & 0.998 \\
\hline Pre. $\mathrm{R}^{2}$ & 0.996 & 0.996 & 0.966 & 0.999 & 0.966 & 0.999 & 0.999 \\
\hline Ad. Pre. & 576.034 & 1687.292 & 62.845 & 1687.292 & 62.845 & 1071.694 & 99.732 \\
\hline CV & 0.065 & 0.017 & 0.510 & 0.016 & 0.510 & 0.014 & 0.730 \\
\hline
\end{tabular}

* Significant at $\mathrm{p}<0.05$

Table 4: Analysis of variance for the Extraction of LSO

\begin{tabular}{|c|c|c|c|c|c|c|}
\hline Reponses & Source & Sum of Square & DF & Mean Square & F- Ratio & p-Value \\
\hline \multirow{5}{*}{$\begin{array}{l}\text { Oil Yield: } \\
\qquad Y_{1}\end{array}$} & Model & 110.46 & 9 & 12.27 & 40524.77 & $0.0001^{*}$ \\
\hline & Residual & 0.00 & 7 & 0.00 & \multirow{3}{*}{0.00} & \multirow{3}{*}{1.0000} \\
\hline & Lack of Fit & 0.00 & 3 & 0.00 & & \\
\hline & Pure Error & 0.00 & 4 & 0.00 & & \\
\hline & Cor Total & 110.46 & 16 & & & \\
\hline \multirow{5}{*}{$\begin{array}{l}\text { Specific Gravity } \\
\qquad \mathrm{Y}_{2}\end{array}$} & Model & $4.04 \times 10^{-4}$ & 9 & $4.49 \times 10^{-5}$ & 210200.22 & $0.0001^{*}$ \\
\hline & Residual & $1.49 \times 10^{-9}$ & 7 & $2.14 \times 10^{-10}$ & \multirow{3}{*}{0.0000} & \multirow{3}{*}{1.0000} \\
\hline & Lack of Fit & 0.0000 & 3 & 0.00 & & \\
\hline & Pure Error & $1.49 \times 10^{-9}$ & 4 & $3.74 \times 10^{-10}$ & & \\
\hline & Cor Total & $4.04 \times 10^{-4}$ & 16 & & & \\
\hline \multirow{5}{*}{$\begin{array}{l}\text { Acid Value } \\
\qquad \mathrm{Y}_{3}\end{array}$} & Model & 0.57 & 9 & 0.06 & 319.13 & $0.0001^{*}$ \\
\hline & Residual & $1.40 \times 10^{-3}$ & 7 & $2.00 \times 10^{-4}$ & \multirow{3}{*}{7.89} & \multirow{3}{*}{0.0574} \\
\hline & Lack of Fit & $1.20 \times 10^{-3}$ & 3 & $4.000 \times 10^{-4}$ & & \\
\hline & Pure Error & $2.02 \times 10^{-4}$ & 4 & $5.06 \times 10^{-5}$ & & \\
\hline & Cor Total & 0.58 & 16 & & & \\
\hline Saponification Value & Model & 424.32 & 9 & 47.15 & 210200.22 & $0.0001^{*}$ \\
\hline $\mathrm{Y}_{4}$ & Residual & $1.57 \times 10^{-3}$ & 7 & $2.24 \times 10^{-4}$ & & \\
\hline
\end{tabular}


Process Optimisation and Characterisation of Fragrance Suited Mechanically Expressed Nigerian ..., A. G. Adeniyi, et al.

\begin{tabular}{|c|c|c|c|c|c|c|}
\hline Reponses & Source & Sum of Square & DF & Mean Square & F- Ratio & p-Value \\
\hline & Lack of Fit & 0.00 & 3 & 0.00 & 0.00 & 1.0000 \\
\hline & Pure Error & $1.57 \times 10^{-3}$ & 4 & $2.24 \times 10^{-4}$ & & \\
\hline & Cor Total & 424.32 & 16 & & & \\
\hline \multirow{5}{*}{$\begin{array}{l}\text { FFA } \\
\mathrm{Y}_{5}\end{array}$} & Model & 0.57 & 9 & 0.06 & 319.13 & $0.0001^{*}$ \\
\hline & Residual & $1.40 \times 10^{-3}$ & 7 & $2.00 \times 10^{-4}$ & & \\
\hline & Lack of Fit & $1.20 \times 10^{-3}$ & 3 & $4.00 \times 10^{-4}$ & 7.89 & 0.0574 \\
\hline & Pure Error & $2.023 \times 10^{-4}$ & 4 & $5.06 \times 10^{-5}$ & & \\
\hline & Cor Total & 0.58 & 16 & & & \\
\hline \multirow{5}{*}{$\begin{array}{l}\text { Iodine value } \\
\qquad \mathrm{Y}_{6}\end{array}$} & Model & 229.66 & 9 & 25.52 & 112450.30 & $0.0001^{*}$ \\
\hline & Residual & $1.59 \times 10^{-3}$ & 7 & $2.27 \times 10^{-4}$ & & \\
\hline & Lack of Fit & 0 & 3 & 0.00 & 0.00 & 1.0000 \\
\hline & Pure Error & $1.59 \times 10^{-3}$ & 4 & $3.97 \times 10^{-4}$ & & \\
\hline & Cor Total & 229.67 & 16 & & & \\
\hline \multirow{5}{*}{$\begin{array}{l}\text { Peroxide Value } \\
\qquad \mathrm{Y}_{7}\end{array}$} & Model & 110.35 & 9 & 12.26 & 938.69 & $0.0001^{*}$ \\
\hline & Residual & 0.09 & 7 & 0.013 & & \\
\hline & Lack of Fit & 0.00 & 3 & 0.00 & 0.00 & 1.0000 \\
\hline & Pure Error & 0.09 & 4 & 0.02 & & \\
\hline & Cor Total & 110.44 & 16 & & & \\
\hline
\end{tabular}

* Significant at $\mathrm{p}<0.05$

$$
\begin{gathered}
Y_{1}=-30970+7.88 X_{1}+4.94 X_{2}+4.91 X_{3}-0.047_{1}^{2}-0.039_{2}^{2}-0.039_{3}^{2}-0.047 X_{1} X_{2}-0.047 X_{1} X_{3}+0.047 X_{2} X_{3} \\
Y_{2}=-0.38+0.029 X_{1}+0.014 X_{2}+0.014 X_{3}-1.61 \times 10^{-4} X_{1}^{2}-1.59 \times 10^{-4} X_{2}^{2}-1.59 \times 10^{-4} X_{3}^{2}-1.61 \times 10^{-4} X_{1} X_{2}-1.61 \\
\times 10^{-4} X_{1} X_{3}-1.61 \times 10^{-4} X_{2} X_{3} \\
Y_{3}=-20.80+0.59 X_{1}+0.16 X_{2}+0.49 X_{3}-3.57 \times 10^{-4} X_{1}^{2}-4.15 \times 10^{-4} X_{1} X_{2} \\
Y_{4}=-1087.49+2937 X_{1}+13.87 X_{2}-0.17 X_{2}^{2}-0.16 X_{3}^{2}-0.17 X_{1} X_{2}-0.17 X_{1} X_{3}-0.17 X_{2} X_{3} \\
Y_{5}=-1040+029 X_{1}+0.08 X_{2}+0.24 X_{3}-1.79 \times 10^{-4} X_{1}^{2}-2.08 \times 10^{-4} X_{1} X_{3}
\end{gathered}
$$

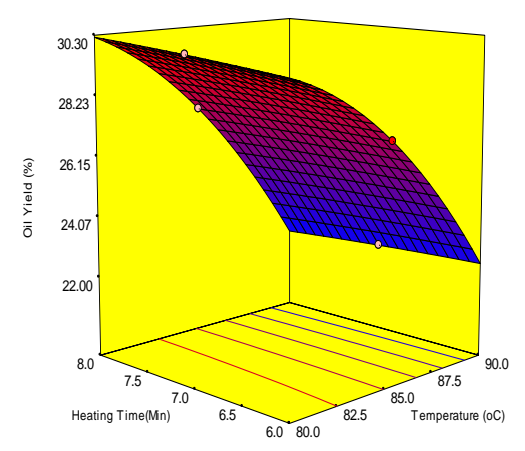

a

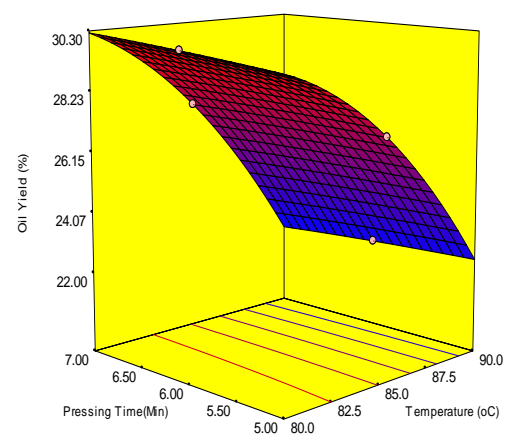

b

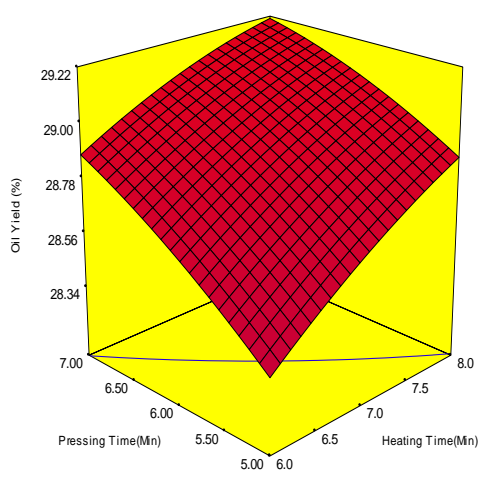

c

Figure 9: Effects of ptocess parameters on the LSO yield

In determining the optimal process parameters that maximizes the LSO yield and that satisfy chemical and physical properties stated by Codex Alimentarium Commission [25,28], the following constraints were imposed: specific gravity (0.855 -0.863), acid value $(\leq 4$ $\mathrm{mg} \mathrm{KOH} / \mathrm{g})$; saponification value (184 -190 mgKOH/g), FFA $(\leq 1.5 \%)$, Iodine value $\left(\leq 115 \mathrm{~g} \mathrm{I}_{2} / 100 \mathrm{~g}\right)$ and peroxide value $(\leq 15 \mathrm{meq} / \mathrm{kg})$. Then the optimisation problem was solved using RSM optimization routing in Design Expert 7.0 version. A maximum of $29.21 \%$ of
LSO yield was obtained with specific gravity (0.861), acid value (2.86 mg $\mathrm{KOH} / \mathrm{g})$; saponification value (185.3 mgKOH/g), FFA (1.43 \%), Iodine value (107.8 g $\left.\mathrm{I}_{2} / 100 \mathrm{~g}\right)$ and peroxide value $(15 \mathrm{meq} / \mathrm{kg})$. These were obtained at heating temperature $\left(83^{\circ} \mathrm{C}\right)$; preheating time (8 $\mathrm{min})$ and pressing time $(7 \mathrm{~min})$. The 3D plot along with the contour to estimate optimum value for the three factors considered are shown in Figure 9. The combined effect of heating temperature and heating time on LSO yield is as shown on Figure 9a, 
heating temperature and pressing time (Figure 9b) and, heating time and pressing time in Figure 9c.

To verify the prediction of the model, the optimal condition values were applied to three independent replicates and the average oil yield obtained was 29.13 $\%(\mathrm{w} / \mathrm{w})$. The averages as well as the standard values of chemical and physical characteristics of the oils obtained demonstrate that RSM with appropriate experimental design can be effectively applied to the optimization of the process factors in oil extraction work as shown in Table 5.

The GC-MS analysis identified the presence of thirteen components in the oil and the identified components were composed of fatty acids, carboxylic acids, aromatic substances and other minor compounds. The prominent fatty acids in lime seed oil are palmitic acid, stearic acid and oleic acid are as shown in Table 6 . Palmitic acid is a saturated fatty acid and has the highest composition of $35.15 \%$ which implies it is the major saturated fatty acid in the oil. Palmitic acid is used to produce soaps and cosmetics. Stearic acid is a saturated fatty acid with a composition of $1.94 \%$. Steric acid is used to produce soaps, cosmetics, detergents, lubricants, softening agents and dietary supplements. Oleic acid is a monounsaturated omega-9 fatty acid with a composition of $1.84 \%$. Oleic acid is used to produce soaps, dietary supplements, cosmetics, pharmaceuticals and, it is also used as an emulsifying or solubilizing agent in aerosol products. The oil also contains carboxylic acids (diacetic acid and benzoic acid; 2.39 and $1.67 \%$ in composition respectively) which can be used to produce dyes and used as food preservatives.

\section{CONCLUSSION}

The Nigeria lime seed oil extracted is well suited for frangrance making due to its conformity to the International Fragrance Association's requirments.This feat has been made possible by the successful application of Box Behnken experimetal design to determine the optimal process conditions for maximum lime seed oil yield that satified the standard requirments. The lime seed oil has been established to be a rich source of unsaturated fatty acids and aromatic compounds which can be utilized for fragrance production.

\section{REFERENCES}

[1] Kovo, A. S. "Application of full $4^{2}$ Factorial Design for the Development and Characterization of Insecticidal Soap from Neem Oil." Leonard Electronic Journal Practice and Technology, 8, , pp 29-40, 2006.

[2] Adepoju, T. F. and Okunola, A. A. "Statistical Approach to Oils Extraction from Sorrel Seed (Hibiscus sabdariffa L.) and Its Quality Characterization" International Journal of Scientific and Engineering Research, 4 (9), pp 112. , 2013.

[3] Orhevba, B. A., Chukwu, O., Osunde, Z. D. and Ogwuagwu, V. "Studies on The Effect of Pressure on Yield of Mechanically Expressed Neem Seed Kernel Oil". Global Journal of Engineering Design and Technology, 2(5), pp 20-24, 2013.

Table 5: Physico-Chemical properties of LSO at optimal condition

\begin{tabular}{lll}
\hline Properties & Unit & Value \\
\hline Oil yield & $\%$ & $29.13( \pm 0.42)$ \\
Speciifc gravity & & $0.858( \pm 0.032)$ \\
Acid value & $\mathrm{mg} \mathrm{KOH} / \mathrm{g}$ & $2.74( \pm 0.36)$ \\
Saponification value & $\mathrm{mg} \mathrm{KOH} / \mathrm{g}$ & $188.36( \pm 3.42)$ \\
FFA & $\%$ & $1.37( \pm 0.18)$ \\
Iodine value & $\mathrm{mg} / 100 \mathrm{~g}$ oil & $106.62( \pm 0.92)$ \\
Peroxide value & $\mathrm{meq} / \mathrm{kg}$ & $16.2( \pm 1.02)$ \\
\hline
\end{tabular}

Table 6: Fatty Acids in Lime Seed Oil

\begin{tabular}{llll}
\hline Component & Formula & Systemic name & wt \% \\
\hline Palmitic acid & $\mathrm{C}_{16} \mathrm{H}_{32} \mathrm{O}_{2}$ & Hexadecanoic & 35.15 \\
Stearic acid & $\mathrm{C}_{18} \mathrm{H}_{36} \mathrm{O}_{2}$ & Octadecanoic & 1.94 \\
Oleic acid & $\mathrm{C}_{18} \mathrm{H}_{34} \mathrm{O}_{2}$ & cis-9-Octadecenoic & 1.84 \\
Diacetic acid & $\mathrm{C}_{4} \mathrm{H}_{6} \mathrm{O}_{3}$ & 3-oxobutanoic acid & 2.39 \\
Benzoic acid & $\mathrm{C}_{7} \mathrm{H}_{6} \mathrm{O}_{2}$ & Phenylmethanoic acid & 1.67 \\
Aromatic substance & & & 53.11 \\
Other compounds & & & 3.9 \\
\hline
\end{tabular}


[4] Aluyor, E. O., Obahiagbon, K. O. and Ori-jesu, M. "Biodegradation of vegetable oils: A review". Scientific Research and Essay, 4(6), pp 543-548, 2009.

[5] Musa, U., Isah, A. G., Mohammed, I. A., Mohammed, U. G. and Usman, Z. "Extraction of Chrysophyllum albidum Seed Oil: Optimization and Characterization". Chemical and Process Engineering Research, 30, pp. 1-8, 2015.

[6] Ibrahim, A. and Onwualu, A. P. "Technologies For Extraction of Oil From Oil - Bearing Agricultural Producs: A Review". Journal of Agricultural Engineering and Technology, 13, pp 58 -89, 2005.

[7] Njoku, V. I. and Evbuomwan, B. O. "Quantitative and Qualitative analysis, and comparative study of essential oil extracted from Nigerian orange, lemon and lime peels". International Journal of Applied Science and Engineering Research, 3(2), pp 519 - 531,2014.

[8] Azar, P. A., M., N., Larijani, K. and Bahramnasab, S. "Chemical composition of the essential oils of Citrus sinensis cv. Valencia and a quantitative structure-retention relationship study for the prediction of retention indices by multiple linear regression Journal of the Serbian Chemical Society, 76(12), pp1627 -1637, 2011.

[9] Atolani, 0., Omere, J., Otuechere, C. A. and Adewuyi, A. "Antioxidant and cytotoxicity effects of seed oils from edible fruits. Journal of Acute Disease, 1(2), pp130-134, 2012.

[10] Olaniyan, A. M. "Effect of Extraction Conditions on The Yield and Quality of Oil From Castor Bean". Journal of Cereals and Oil seeds, 1(2), , pp 24-33, 2010.

[11] Deli, S., Farah- Masturah, M., Tajul - Aris, Y. and Wan - Nadiah, W. A. "The Effects of physical parameters of the screw press oil expeller on oil yield from Nigella sativa L seeds". International Food Research Journal, 18(4), , 1367-1373, 2011.

[12] Mahmud, S., Akhtar, H., Saleem, M. and Khanum, R. "Lipid classes of in vitro cultivar of Pakistani citrus". Journal of Saudi Chemical Society, 13(3), 299-302, 2009.

[13] Matthaus, B. and Özcan, M. M. "Chemical evaluation of citrus seeds, an agro-industrial waste, as a new potential source of vegetable oils". Grasas Y Aceites, 63(3), 313 - 320, 2012.

[14] Orhevba, B. A., Sunmonu, M. O.and Iwunze, H. I." Extraction and Characterization of Moringa oleifera Seed Oil". Research \& Reviews: Journal of Food and Dairy Technology, 1(1), pp 22-27, 2013.

[15] Kamal, G. M., Anwar, F., Hussain, A. I., Sarri, N. and Ashraf, M. Y. "Yield and chemical composition of
Citrus essential oils as affected by drying pretreatment of peels". International Food Research Journal, 18(4), 1275-1282, 2011.

[16] Kosseva, M. R. "Processing of Food Wastes" Advances in Food and Nutrition Research, 58, 57 136. Academic Press. 2009.

[17] Ajewole, K. and Adeyeye, A. "Characterisation of Nigerian citrus seed oils", Food Chemistry, 47, , pp 77-78, 1993.

[18] Anwar, F., Naseer, R. and Bhanger, M.I." PhysicoChemical Characteristics of Citrus Seeds and Seed Oils from Pakistan". Journal of American Oil Chemical Society, 85, pp 321-330, 2008.

[19] Manaf, Y. N. A., Osman, A., Lai, O. M., Long, K. and Ghazali, H.M. "Characterisation of musk lime (Citrus microcarpa) seed oil " Journal of the Science of Food and Agriculture, 88, pp. 676-683, 2008.

[20] Aranha, C.P.M. and Jorge, N. " Physico-chemical Characterization of Seed Oils Extracted from Oranges (Citrus sinensis)" Food Science and Technology Research, 19 (3), pp 409 - 415, 2013.

[21] Reazai, M.,Mohammadpourfard,I., Nazmara, S., Jahanbakhsh, M. and Shiri, L. " Physicochemical Characteristics of Citrus Seed Oils from Kerman, Iran ". Journal of Lipids, 174954,pp1-3, 2014.

[22] Liauw, M. Y., Natan, F. F., Widiyanti, P., Ikasari, D., Indraswati, N.and Soetaredjo, F. E. "Extraction of Neem Oil (Azadirachta Indica A. Juss) Using NHexane And Ethanol: Studies Of Oil Quality, Kinetic and Thermodynamics". ARPN Journal of Engineering and Applied Sciences, 3(3), pp 49-54, 2008.

[23] Kasote, D.M., Badhe, Y.S., Hegde, M.V. "Effect of mechanical press oil extraction processing on quality of linseed oil". Industrial Crops and Products , 42:10-13. 2013.

[24] Olajide, J. O., Afolabi, T. J. and Adeniran, J. A. Optimization of Oil Yield from Groundnut Kernel (Arachis hypogeae) in an Hydraulic Press Using Response Surface Methodology. Journal of Scientific Research \& Reports ,3 (14), 2014, pp 1916-1926.

[25] Codex Alimentarium Commission. Codex Stan 210-1999: codex standard for named vegetable oils. $2015 \mathrm{a}$.

[26] International Fragrance Association. IFRA Standards for Fragrance, 2016.

[27] AOAC.. Official Methods of Analysis. AOAC, International Maryland: USA, 2005. 
[28] Codex Alimentarium Commission. Codex Stan 191981: standard for edible fats and oils not covered by individual standards, $2015 \mathrm{~b}$.

[29] Kyari, M. Z. "Extraction and characterization of seed oils". International Journal of Agrophysics, 22, 2008, pp139 - 142.

[30] Ogungbenle, H. N.and Omodara, O. P. "Physicochemical and fatty acid composition of Nicker Bean (Entada gigas) seed oil". Advances in Analytical Chemistry. 4(2), pp35-39, 2014.

[31] Chindo, I. Y., Gushit, J. S., Olotu, P. N., Mugana, J. and Takbal, D. N. "Comparism of the quality parameters of the seed and condiment oil of Adansonia Digitata." Journal of American Science, 6(12), pp 990 - 994, 2010.

[32] Audu, T. O. K., Aluyor, E. O., Egualeona, S. and Momoh, S. S. "Extraction and Characterization of Chrysophyllum albidum and Luffa cylindrica Seed Oils". Petroleum Technology Development Journal, 3(1), pp 1- 7, 2013.

[33] Babalola, T. O. O. and Apata, D. F.. Chemical and quality evaluation of some alternative lipid sources for aquafeed production. Agriculture and Biology Journal of North America. 2(6), 936 - 943, 2011.

[34] Zahir, E., Saeed, R., Hameed, M. A., Yousuf, A.. Study of physicochemical properties of edible oil and evaluation of frying oil quality by Fourier Transform-Infrared (FT-IR) Spectroscopy. Arabian Journal of Chemistry. http://doi.org/10.1016/j.arabjc.2014.05.025, 2014.
[35] Van De Mark, M.R., and Sandefur, K. "Vegetable oils in paint and coatings. In: "Industrial uses of vegetable oils”. AOCS Press. 16(8), pp. 478-481, 2005.

[36] Nwobi, B. E., Ofoegbu, 0. O. and Adesina, O. B. "Extraction and Qualitative Assessment of African Sweet Orange Seed Oil". African Journal of Food Agriculture Nutrition and Development, 6(2) pp 1-11, 2006.

[37] Kittiphoom, S. and Sutasinee, S. "Mango seed kernel oil and its physicochemical properties". International Food Research Journal, 20(3), 1145 - 1149, 2013.

[38] Anyasor, G. N., Ogunwenmo, K. O., Oyelana, O. A., Ajayi, D. and Dangana, J. 'Chemical Analyses of Groundnut (Arachis hypogaea) Oil”. Pakistan Journal of Nutrition, 8(3), pp 2269 - 2272, 2009.

[39] Atinafu, D. G., Bedemo, B. "Estimation of total free fatty acid and cholesterolcontent in some commercial edible oils in Ethiopia, Bahir DAR". Journal of Cereals and Oil seeds, 2(6), pp 71-76, 2011.

[40] Reed, G.F., Lynn, F. and Meade, B. D. "Use of Coefficient of Variation in Assessing Variability of Quantitative Assay." Clinical and Diagnostic Laboratory Immunology, 9(6), 1235-1239, 2002.

[41] Agarry, S. E. and Ogunleye, O. O. "Box-Behnken Designs Application to Study Enhanced Bioremediation of Soil Artificially Contaminated with Spent Engine Oil Using Biostimulation Strategy". International Journal of Energy and Environmental Engineering, 3, pp 31, 2012. 